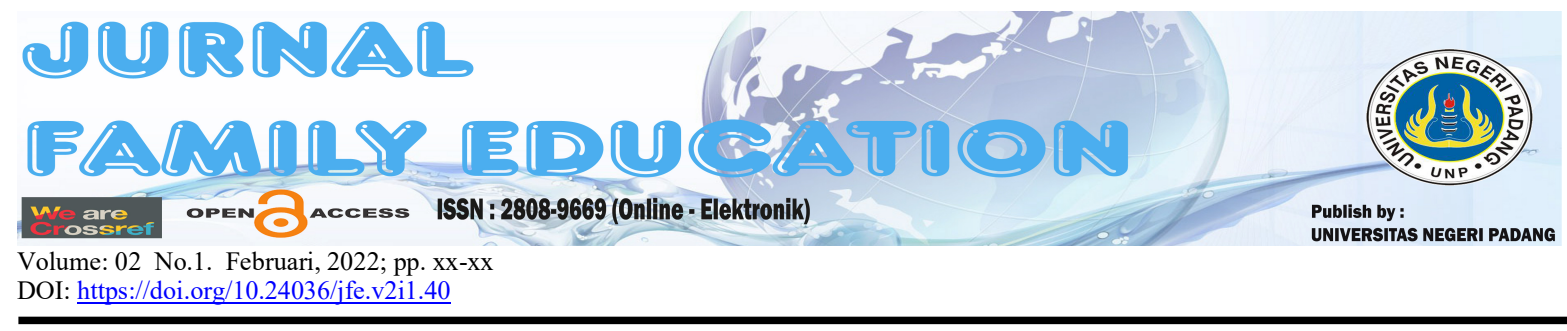

\title{
Hubungan Antara Media Pembelajaran Online Dengan Hasil Belajar Kelas Viii.7 Dan Viii.8 Pada Kegiatan Ektrakulikuler Pramuka
}

\author{
Dela Febrian, Wirdatul A'ini \\ Universitas Negeri Padang \\ * e-mail: dela.febrian09@gmail.com
}

\begin{abstract}
This exploration is persuaded by the low learning results of understudies in grades VIII. 7 and VIII.8 in scout extracurricular activities at SMP Negeri 7 Padang, this is apparently in light of the fact that it has something to do with internet learning media. This review expects to portray the utilization of web based learning media and see the connection between web based learning media and learning results for grades VIII.7 and VIII.8 in scout extracurricular exercises at SMP Negeri 7 Padang. This examination was directed utilizing a quantitative methodology with a correlational sort. The populace in this review were 62 understudies of class VIII.7 and VIII.8 who partook in scout extracurricular exercises. Tests were taken involving the propotionate delineated arbitrary examining method upwards of 38 individuals. Information assortment strategies through circulating surveys. The information investigation method utilizes the rate and item second recipes. The outcomes showed that web based learning media as per understudies was classified as low and there was a huge connection between web based learning media and the learning results of class VIII.7 and VIII.8 students who participated in scout extracurricular activities at SMP Negeri 7 Padang. It is expected that scout extracurricular coaches will use online learning media because it is related to student learning outcomes and it is recommended for other researchers to be able to look for other variables that affect student learning outcomes in extracurricular activities..
\end{abstract}

Keywords: Online Learning Media, learning outcomes

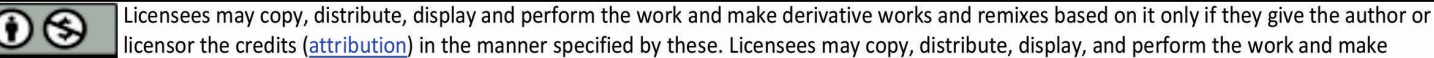
derivative works and remixes based on it only for non-commercial purposes.

\section{PENDAHULUAN}

Pendidikan Pendidikan merupakan salah satu komponen penting dalam kemajuan suatu negara yang harus dilaksanakan oleh setiap warga negaranya. Adanya pendidikan akan mewujudkan manusia cerdas, disiplin, berkarakter baik dan memiliki kemampuan yang mumpuni untuk kemajuan suatu bangsa. Pendidikan nonformal menjadi topik yang menarik karena merupakan pelengkap dari pendidikan formal. Sebagian besar sasaran dari pendidikan nonformal merupakan lapisan masyarakat yang tidak dibatasi oleh usia, jenis kelamin, tingkat sosial ekonomi dan status pendidikan sebelumnya. Tujuan pendidikan nonformal tidak hanya terfokus pada peserta yang tidak bersekolah, berhenti sekolah, peserta yang sudah lulus sekolah, atau peserta yang ingin bekerja ('Aini, 2006). Oleh karena itu, pendidikan nonformal diperlukan agar dapat 
melayani seluruh lapisan masyarakat seperti halnya individu-individu yang sudah memiliki tingkat pendidikan lanjutan atau yang sudah bekerja. Ini menunjukan bahwa peserta yang mengikuti pendidikan nonformal adalah individu yang membutuhkan lebih banyak pengetahuan dan keterampilan dalam mengembangkan potensi diri yang mengacu pada hakekat pendidikan sepanjang hayat (Sunarti, 2014).

Program pendidikan nonformal yang bisa mengembangkan kemampuan peserta didik salah satunya adalah program ekstrakulikuler. Wiyani (2013) mengatakan bahwa ekstrakulikuler ialah pendidikan kepemudaan yang terdapat di sekolah yang dilaksanakan untuk menyokong kemajuan peserta didik mulai dari potensi, minat dan bakat serta keinginan peserta didik lewat kegiatan yang dilaksanakan oleh sekolah yang penyelenggaraannya di luar jam sekolah. Salah satu kegiatan ekstrakulikuler yang wajib dilaksanakan disetiap sekolah yaitu prmuka. Dalam Undang-Undang Nomor 63 Tahun 2014 pasal (1) disebutkan bahwa pramuka ialah ekstrakulikuler wajib untuk dijalanani oleh semua peserta didik disemua jenjang pendidikan dengan tujuan membantu pengemb angan karakter, perilaku dan kecakapan hidup peserta didik. Kepramukaan adalah suatu kegiatan yang bertujuan membentuk pribadi dan karakter peserta didik yang diharapkan bisa menjadi salah satu kegiatan yang membantu peserta didik untuk mau berkompetisi atau mempunyai daya saing dalam melakukan kegiatan pelatihan yang diberikan sehingga peserta didik memiliki motivasi untuk berprestasi pada semua kegiatan pelatihan yang mereka ikuti (Kurniati \& Jalius, 2020).

Berdasarkan pengamatan yang peneliti lakukan terhadap dua kelas pada tanggal 25 Maret3 Juni saat kegiatan ekstrakulikuler pramuka dilaksanakan melalui geschool peserta didik ada yang aktif dalam kegiatan, bertanya, mengerjakan latihan dan menyelesaikan tugas dengan baik. Tetapi terdapat juga peserta didik yang pasif dalam kegiatan, tidak hadir dan tidak mengerjakan latihan yang diberikan. Ketekunan peserta didik dalam mengikuti rangkaian pembelajaran sangat memperngaruhi hasil belajar peserta didik tersebut. Seperti yang dikatakan oleh Arifin (2010) bahwa hasil belajar dapat dikatakan ideal apabila peserta didik cakap dalam menyelesaikan tugas yang diberikan pendidik, mempunyai pemahaman yang terbuka terhadap pengetahuan dan ketuntasan belajarnya. Sementara itu Susanto (2013) mengatakan jika belajar dapat dikatakan berhasil apabila peserta didik mampu memahami pembelajaran yang diberikan pendidik yang dibuktikan dengan nilai berupa angka yang didapat dari hasil ujian mengenai pembelajaran sebelumnya. Mengikuti pandangan para ahli diatas di SMP Negerri 7 Padang ditemukan peserta didik yang mendapatkan hasil belajar rendah, seperti tidak menuntaskan tugas yang diberikan oleh pembina, serta hasil tes tidak mencapai batas KKM yang sudah ditentukan. KKM yang ditetapkan oleh SMP Negeri 7 Padang yaitu 81, maka peserta didik yang mendaptkan nilai dibawah 81 dinyatakan tidak tuntas.

Berdasarkan data yang peneliti peroleh dari pembina ekstrakulikuler pramuka di SMP Negeri 7 Padang bernama ibu Rika Susiwaty, S.Pd pada tanggal 15 April 2021, beliau mengatakan bahwa hasil belajar peserta didik pada kegiatan ekstrakulikuler pramuka dua kelas yaitu kelas VIII.7 dan VIII.8 rendah karena ketika melaksanakan kegiatan pembelajaran online terdapat lebih dari $50 \%$ peserta didik tidak hadir, pasif dalam proses pembelajaran, tidak menjawab pertanyaan serta tidak menyelesaikan tugas dari pembina.

Rendahnya hasil belajar kelas VIII.7 dan VIII.8 pada kegiatan ekstrakulikuler pramuka di SMP Negeri 7 Padang juga dapat dilihat dari laporan penilaian ekstrakulikuler pramuka semester dua (2) TP. 2020-2021 yang peneliti peroleh dari pembina pramuka ibu Rika Susiwaty, S.Pd dan ibu Mardiati, S.Pd selaku pembimbing pramuka kelas VIII.8. 
Tabel 1. Hasil belajar kelas VIII.7 dan VIII.8 pada kegiatan ekstrakulikuler pramuka.

\begin{tabular}{|c|c|c|c|c|}
\hline No & Hasil Belajar & Jumlah (orang) & Lulus (orang) & Tidak Lulus (orang) \\
\hline 1 & Kelas VIII.7 & 32 & 15 & 17 \\
\hline 2 & Kelas VIII.8 & 30 & 12 & 18 \\
\hline \multicolumn{2}{|c|}{ Jumlah } & 62 & 26 & 35 \\
\hline
\end{tabular}

\section{Sumber: Data SMP Negeri 7 Padang}

Peneliti mengira bahwa rendahnya hasil belajar peserta didik mempunyai hubungan dengan media pembelajaran yang dipakai. Pemanfaatan media pembelajaran dalam sistem pembelajaran mempengaruhi hasil belajar peserta didik. Sebagaimana ditunjukkan oleh Rusman (2013) bahwa tinggi rendahnya hasil belajar dapat dipengaruhi oleh beberapa faktor, antara lain faktor dari dalam diri peserta didik itu sendiri, misalnya keadaan fisik dan mentalnya dan faktor dari luar peserta didik seperti iklim belajar dan perangkat pembelajaran. Media pembelajaran adalah satu dari beberapa perangkat pembelajaran.

Sejalan dengan yang pendapat Rudi Susilana dan Cepi Riyana (2009) bahwa media pembelajaran ialah sarana yang digunakan oleh pembina untuk menyampaikan materi menggunakan alat bantu visual yang berguna untuk menambah motivasi belajar, merincikan dan menyederhanakan konsep yang abstrak serta meningkatkan penguasaan atau retensi pembelajaran peserta didik. Media pembelajaran membuat kegiatan pembelajaran menjadi lebih bermakna dan membangkitkan semangat peserta didik untuk berpartisipasi dalam pembelajaran. Berdasarkan penjelasan tersebut, pemanfaatan media pembelajaran dalam kegiatan pembelajaran mempengaruhi semangat dalam melakukan kegiatan pembelajaran (Mutmainnah \& Ismaniar, 2018). Disebabkan karena pandemi Covid 19, SMP Negeri 7 Padang menggunakan sistem pembelajaran online sehingga media pembelajaran yang digunakan juga media pembelajaran online.

Dari fenomena tersebut, peneliti ingin melihat hubungan antara media pembelajaran online dengan hasil belajar kelas VIII.7 dan VIII.8 pada kegiatan ekstrakulikuler pramuka di SMP Negeri 7 Padang. Seterlah diuraikan permasalahan di atas, peneliti tertarik untuk melakukan penelitian dengan judul Hubungan Media Pembelajaran Online dengan Hasil Belajar Kelas VIII.7 dan VIII.8 pada Kegiatan Ekstrakulikuler Pramuka di SMP Negeri 7 Padang.

\section{METODE}

Penelitian ini memakai pendekatan kuantitatif dengan jenis korelasional, bertujuan untuk melihat hubungan suatu variabel. Sugiyono (2017) mengemukakan bahwa penelitian dengan pendekatan kuantitatif jenis korelasional merupakan jenis penelitian yang dipakai untuk melihat ada tidaknya hubungan kedua variabel. Populasi dari penelitian ini adalah peserta didik kelas VIII.7 dan VIII.8 yang mengikuti kegiatan ekstrakulikuler pramuka di SMP Negeri 7 Padang sebanyak 62 orang. Sampel dari penelitian ini sebanyak 38 orang yang diambil dengan teknik propotionate stratified random sampling. Teknik pengumpulan data berupa penyebaran angket. Teknik analisis data memakai rumus persentase dan korelasi product moment.

\section{HASIL PENELITIAN}

Hasil penelitian ini menyangkut gambaran tentang penggunaan media pembelajaran online kelas VIII.7 dan VIII.8 dan hubungan antara media pembelajaran online dengan hasil belajar kelas VIII.7 dan VIII.8 pada kegiatan ekstrakulikuler pramuka di SMP Negeri 7 Padang. Untuk lebih jelasnya dapat dilihat dari penjabaran di bawah ini. 
Deskripsi Media Pembelajaran Online yang Digunakan Kelas VIII.7 dan VIII.8 pada Kegiatan Ekstrakulilkuler Pramuka di SMP Negeri 7 Padang

Data mengenai media pembelajaran online yang digunakan pada kegiatan ekstrakulikuler pramuka di SMP Negeri 7 Padang terbagi menjadi 5 indikator, yaitu : 1) Kemenarikan terdiri dari 9 item pernyataan; 2) Kesesuaian yang terdiri dari 5 item pernyataan; 3) Keunikan yang terdiri dari 4 item pernyataan; 4) Interaktif yang terdiri dari 4 item pernyataan; dan 5) Dinamis yang terdiri dari 6 item pernyataan.

Secara keseluruhan variabel media pembelajaran online berjumlah 28 butir dan disebarkan kepada 38 peserta didik sebagai responden penelitian. Selengkapnya bisa dilihat dari diagram rekapitulasi media pembelajaran online pada kegiatan ekstrakulikuler pramuka di smp negeri 7 padang berikut.

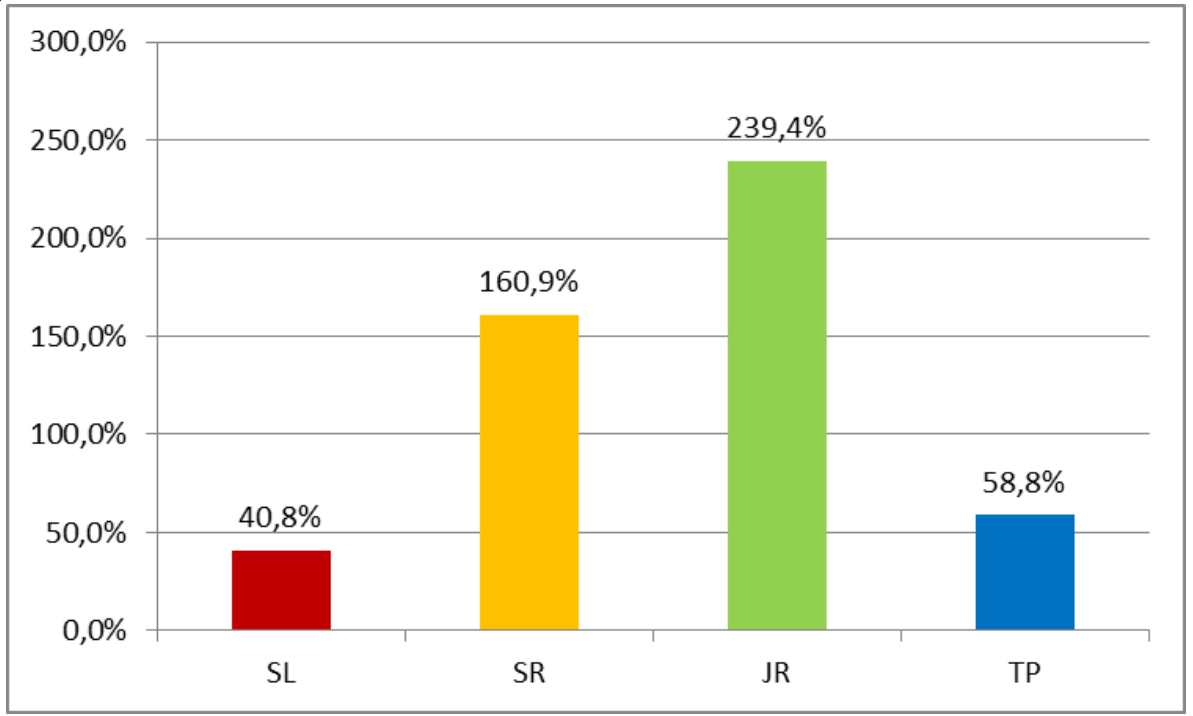

Dari data tersebut diketahui bahwa media pembelajran online menurut peserta didik di SMP Negeri 7 Padang, responden memilih jawaban pilihan Selalu (SL) sebanyak 40,8\%, memilih jawaban Sering (SR) sebanyak 160,9\%, memilih jawaban Jarang (JR) sebanyak 239,4\% dan memilih jawaban Tidak Pernah (TP) sebanyak sebagai 58,8\% Dari hasil rekapitulasi media pembelajaran online yang digunakan pada kegiatan ekstrakulikuler pramuka yang disebarkan kepada 38 responden dengan 5 indikator dapat disimpulkan bahwa penggunaan media pembelajaran online pada kegiatan ekstrakulikuler tersebut masih kurang menarik, kurang sesuai, kurang unik, kurang interaktif dan kurang dinamis.

Hubungan antara Media Pembelajaran Online dengan Hasil Belajar Kelas VIII.7 dan VIII.8 pada Kegiatan Ekstrakulilkuler Pramuka di SMP Negeri 7 Padang

Data yang berhubungan dengan hubungan antara media pembelajaran online dengan hasil belajar kelas VIII.7 dan VIII.8 pada kegiatan ekstrakulikuler pramuka di SMP Negeri 7 Padang, melalui metode yang yang digunakan untuk menyebarluaskan angket yang diberikan kepada responden, bisa dilihat lebih jelas melalui uraian tabel berikut.

Tabel 1. Analisis Korelasi Media Pembelajaran Online dengan Hasil Belajar Kelas VIII.7 dan VIII.8 yang Mengikuti Ekstrakulikuler Pramuka Di SMP Negeri 7 Padang

\begin{tabular}{|c|c|c|c|c|c|c|}
\hline NO & Inisial & $\mathbf{X}$ & $\mathbf{Y}$ & $\mathbf{X}^{\mathbf{2}}$ & $\mathbf{Y}^{\mathbf{2}}$ & $\mathbf{X . Y}$ \\
\hline 1 & $\mathrm{~A} 1$ & 78 & 89 & 6084 & 7921 & 6942 \\
\hline 2 & $\mathrm{~B} 1$ & 54 & 64 & 2916 & 4096 & 3456 \\
\hline 3 & $\mathrm{C} 1$ & 50 & 66 & 2500 & 4356 & 3300 \\
\hline 4 & $\mathrm{D} 1$ & 70 & 70 & 4900 & 4900 & 4900 \\
\hline 5 & $\mathrm{E} 1$ & 67 & 70 & 4489 & 4900 & 4690 \\
\hline
\end{tabular}


Dela Febrian, Wirdatul' Aini

\begin{tabular}{|c|c|c|c|c|c|c|}
\hline 6 & $\mathrm{~F} 1$ & 78 & 94 & 6084 & 8836 & 7332 \\
\hline 7 & G1 & 68 & 76 & 4624 & 5776 & 5168 \\
\hline 8 & H1 & 50 & 70 & 2500 & 4900 & 3500 \\
\hline 9 & I1 & 77 & 76 & 5929 & 5776 & 5852 \\
\hline 10 & $\mathrm{~J} 1$ & 77 & 82 & 5929 & 6724 & 6314 \\
\hline 11 & K1 & 76 & 86 & 5776 & 7396 & 6536 \\
\hline 12 & L1 & 76 & 92 & 5776 & 8464 & 6992 \\
\hline 13 & M1 & 77 & 94 & 5929 & 8836 & 7238 \\
\hline 14 & N1 & 58 & 64 & 3364 & 4096 & 3712 \\
\hline 15 & $\mathrm{O} 1$ & 57 & 59 & 3249 & 3481 & 3363 \\
\hline 16 & $\mathrm{P} 1$ & 65 & 91 & 4225 & 8281 & 5915 \\
\hline 17 & Q1 & 61 & 92 & 3721 & 8464 & 5612 \\
\hline 18 & $\mathrm{R} 1$ & 69 & 94 & 4761 & 8836 & 6486 \\
\hline 19 & $\mathrm{~S} 1$ & 75 & 86 & 5625 & 7396 & 6450 \\
\hline 20 & $\mathrm{~T} 1$ & 50 & 57 & 2500 & 3249 & 2850 \\
\hline 21 & U1 & 52 & 52 & 2704 & 2704 & 2704 \\
\hline 22 & $\mathrm{~V} 1$ & 57 & 53 & 3249 & 2809 & 3021 \\
\hline 23 & W1 & 71 & 86 & 5041 & 7396 & 6106 \\
\hline 24 & $\mathrm{X} 1$ & 66 & 68 & 4356 & 4624 & 4488 \\
\hline 25 & Y1 & 67 & 88 & 4489 & 7744 & 5896 \\
\hline 26 & $\mathrm{Z1}$ & 69 & 85 & 4761 & 7225 & 5865 \\
\hline 27 & A2 & 60 & 65 & 3600 & 4225 & 3900 \\
\hline 28 & $\mathrm{~B} 2$ & 81 & 93 & 6561 & 8649 & 7533 \\
\hline 29 & $\mathrm{C} 2$ & 58 & 67 & 3364 & 4489 & 3886 \\
\hline 30 & D2 & 68 & 87 & 4624 & 7569 & 5916 \\
\hline 31 & E2 & 75 & 90 & 5625 & 8100 & 6750 \\
\hline 32 & $\mathrm{~F} 2$ & 65 & 58 & 4225 & 3364 & 3770 \\
\hline 33 & G2 & 58 & 53 & 3364 & 2809 & 3074 \\
\hline 34 & $\mathrm{H} 2$ & 63 & 55 & 3969 & 3025 & 3465 \\
\hline 35 & $\mathrm{I} 2$ & 59 & 51 & 3481 & 2601 & 3009 \\
\hline 36 & $\mathrm{~J} 2$ & 73 & 92 & 5329 & 8464 & 6716 \\
\hline 37 & $\mathrm{~K} 2$ & 83 & 96 & 6889 & 9216 & 7968 \\
\hline 38 & $\mathrm{~L} 2$ & 63 & 51 & 3969 & 2601 & 3213 \\
\hline \multicolumn{2}{|c|}{ Jumlah } & 2521 & 2862 & 170481 & 224298 & 193888 \\
\hline
\end{tabular}

Berdasarkan tabel di atas, maka dapat dilakukan perhitungan memakai rumus korelasi product moment sebagai berikutt:

$$
\begin{aligned}
& r_{x y}-\frac{N \sum X Y-\left(\sum X\right)\left(\sum Y\right)}{\sqrt{\left(N \sum X^{2}-\left(\sum X\right)^{2}\right)\left(N \sum Y^{2}-\left(\sum Y\right)^{2}\right)}} \\
& r_{x y}=\frac{38(193888)-(2521)(2862)}{\sqrt{\left(38(170481)-(2521)^{2}\right)\left(38(224298)-(2862)^{2}\right)}} \\
& r_{x y}=\frac{7367744-7215102}{\sqrt{(6478278-6355441)(8523324-8191044)}} \\
& r_{x y}=\frac{7367744-7215102}{\sqrt{(122837)(332280)}}
\end{aligned}
$$




$$
\begin{aligned}
r_{x y} & =\frac{152642}{202030,3897} \\
r_{x y} & =0,75554
\end{aligned}
$$

Berdasarkan hasil analisis tersebut di atas, diperoleh $r_{\text {hitung }}$ sebesar 0,75554 . Nilai $r_{\text {hitung }}$ lebih besar dari pada $r_{\text {tabel }}$ untuk $\mathrm{N}=38$ dengan taraf kepercayaan $95 \%$ sebesar 0.320 , sehingga hasilnya terdapat korelasi yang positif yaitu Ho ditolak dan Ha diterima. Menurut ketetapan koefisien interval yang telah ditetapkan oleh Sugiyono (2017), maka hubungan yang terjadi antara media pembelajaran online dengan hasil belajar kelas VIII.7 dan VIII.8 pada kegiatan ekstrakulikuler pramuka termasuk hubungan yang tinggi. Berdasarkan hasil penelitian ini disimpulkan bahwa "Ada hubungan antara media pembelajaran online dengan hasil belajar kelas VIII.7 dan VIII.8 pada kegiatan ekstrakulikuler pramuka di SMP Negeri 7 Padang”.

\section{PEMBAHASAN}

Setelah melihat dari hasil penelitian yang mengatakan bahwa terdapatnya hubungan yang signifikan antara media pembelajaran online dengan hasil belajar kelas VIII.7 dan VIII.8 pada kegiatan ekstrakulikuler pramuka di SMP Negeri 7 Padang. Berikut ini akan dijelaskan tentang media pembelajaran online dengan hasil belajar kelas VIII.7 dan VIII.8 pada kegiatan ekstrakulikuler pramuka.

\section{Deskripsi Media Pembelajaran Online yang Digunakan Kelas VIII.7 dan VIII.8 pada Kegiatan} Ekstrakulilkuler Pramuka di SMP Negeri 7 Padang

Hasil penelitian menunjukkan bahwa media pembelajaran online yang digunakan menurut peserta didik kelas VIII.7 dan VIII.8 pada kegiatan ekstrakulikuler pramuka di SMP Negeri 7 Padang masih kurang menarik, kurang sesuai, kurang unik, kurang interaktif dan kurang dinamis. Hal tersebut dibuktikan dari banyak responden yang menjawab jarang pada setiap item pernyataan pada angket. Media pembelajaran online yang digunakan pada kegiatan ekstrakulikuler pramuka ini kurang menarik. Hal ini dapat diketahui dari banyaknya responden yang menjawab jarang pada indikator kemenarikan media pembelajaran online. Selain itu, media pembelajaran online yang digunakan kurang sesuai dengan tingkat pendidikan dan pemahaman peserta didik. Selaian kemenarikan dan kesesuaian pada media pembelajaran online, adapun media pembelajaran online yang digunakan juga kurang unik. Serta media pembelajaran online yang digunakan kurang interaktif dan dinamis dilihat dari jawaban responden yang banyak menjawab jarang pada indikator tersebut.

Dengan berbagai pilihan yang beragam dan fitur yang menarik, media pembelajaran online memberikan pengaruh yang besar terhadap pembelajaran. Penggunaan fitur berkirim pesan, penampilan vidio, animasi, melakukan video conference dan berbagai fitur lainnya mampu membangkitkan dan meningkatkan motivasi belajar siswa. Jika media pembelajaran online dimanfaatkan dengan maksimal akan membantu tercapainya tujuan belajar lebih efektif dan efisien.

Dilihat dari penjabaran diatas, bisa ditarik kesimpulan bahwa media pembelajaran online sangat berperan penting dalam mencapai hasil belajar yang diinginkan. Media pembelajaran online yang dimanfaatkan secara baik akan meningkatkan minat dan semangat belajar peserta didik, sehingga itu menjadi salah satu faktor tercapainya hasil belajara yang maksimal.

Hubungan antara Media Pembelajaran Online dengan Hasil Belajar Kelas VIII.7 dan VIII.8 pada Kegiatan Ekstrakulilkuler Pramuka di SMP Negeri 7 Padang

Berdasarkan analisis data yang sudah dikerjakan memakai rumus prosuct moment didapatkan hasil bahwa rhitung $>$ rtabel. Berdasarkan pengolahan data tersebut, dapat ditarik kesimpulan bahwa terdapat hubungan yang siginifikan antara media pembelajaran online dengan hasil belajar kelas VIII.7 dan VIII.8 pada kegiatan ekstrakulikuler pramuka di SMP Negeri 7 Padang. Maka dengan demikian disimpulkan bahwa semakin menarik, sesuai, unik, interaktif dan 
dinamis media pembelajaran online yang digunakan maka hasil belajar peserta didik juga akan semakin baik, sebaliknya apabila media pembelajaran online tidak menarik, sesuai, unik, interaktif dan dinamis maka hasil belajar peserta didik juga akan semakin rendah.

Menurut Dalyono (2012) menyebutkan bahwa hasil belajar bisa dipengaruhi oleh dua faktor, yaitu faktor dalam diri peserta didik dan faktor dari luar diri peserta didik. faktor dalam diri peserta didik terdiri dari keadaan fisik dan psikis, intelegensi dan potensi, keinginan dan semangat belajar dan cara belajar. Sementara itu faktor dari luar diri peserta didik yaitu keluarga, sekolah, masyarakat dan lingkungan. Berdasarkan pendapat diatas, bisa ditarik kesimpulan bahwa terdapat salah satu faktor yang berpengaruh terhadap hasil belajar peserta didik yakni sekolah. Faktor sekolah terdiri dari metode mengajar, kurikulum, media pembelajaran, interaksi antar siswa, alat pengajaran, waktu sekolah, keadaan gedung, tugas rumah dan lain-lain. Media pembelajaran online termasuk salah satu bagian dari faktor sekolah yang mempengaruhi tinggi atau rendahnya hasil belajar yang didapatkan peserta didik. Untuk mendapatkan hasil belajar yang baik, tentunya pendidik perlu menyediakan media pembelajaran online yang maksimal sehingga timbul minat dan semangat belajar untuk mengikuti kegiatan ekstrakurikuler pramuka sehingga hasilnya bisa jadi lebih maksimal.

Dari penjelasan tersebut dapat ditarik kesimpulan bahwa terdapat hubungan yang signifikan antara media pembelajaran online dengan hasil belajar kelas VIII.7 dan VIII.8 pada kegiatan ekstrakulikuler pramuka di SMP Negeri 7 Padang. Semakin menarik, sesuai, unik, interaktif media pembelajaran online yang digunakan maka hasil belajar peserta didik juga semakin baik sebaliknya jika media pembelajaran online tidak menarik, sesuai, unik, interaktif dan dinamis maka hasil belajar peserta didik juga akan rendah.

\section{SIMPULAN}

Kesimpulan dari penelitian hubungan antara media pembelajaran online menurut peserta didik dengan hasil belajar peserta didik kelas VIII.7 dan VIII.8 pada kegiatan ekstrakulikuler pramuka di SMP Negeri 7 Padang sebagai berikut: 1) Media pembelajaran online menurut peserta didik pada kegiatan ekstrakulikuler di SMP Negeri 7 Padang masih kurang menarik, kurang sesuai, kurang unik, kurang interaktif dan kurang dinamis. hal itu dapat dilihat dari hasil pengisian angket oleh responden yang banyak menjawab alternatif jawaban jarang pada media pembelajaran online; 2) dari pengolahan data korelasi menunjukan adanya hubungan yang signifikan anatara media pembelajaran online dengan hasil belajar kelas VIII.7 dan VIII.8 pada kegiatan ekstrakurikuler pramuka di SMP Negeri 7 Padang.

\section{SARAN}

Berdasarkan Saran dari penelitian ini ialah: 1) untuk pembina ekstrakulikuler pramuka bisa menggunakan media pembelajaran online yang menarik, sesuai, unik, interaktif dan dimanis untuk meningkatkan hasil belajar peserta didik; 2) Dikarenakan adanya hubungan yang signifikan anatara media pembelajaran online dengan hasil hasil belajar pada kegiatan ekstrakulikuler pramuka, diharapkan kepada pembina menyediakan media pembelajaran online ketika pembelajaran ekstrakulikuler pramuka; dan 3) untuk para peneliti selanjutnya untuk menemukan varabiabel yang berbeda yang memberikan pengaruh terhadap hasil belajar peserta didik pada kegiatan ekstrakulikuler pramuka. 


\section{REFERENSI}

'Aini, W. (2006). Bahan Ajar Konsep Pendidikan Luar Sekolah. Padang: PLS FIP UNP. Dalyono. (2012). Psikologi Pendidikan. Bandung: Rineka Cipta.

Kurniati, V. S. \& J. (2020). The Relationship Between Activeness Participating In Scout Extracurricular Activities With Student Discipline At SMP 5 Pariaman. Jurnal Spektrum Pendidikan Luar Sekolah, 8(4).

Mutmainnah, F. \& I. (2018). Hubungan Antara Media Pembelajaran Fiqih Menurut Peserta Didik Dengan Motivasi Belajarnya Di MDA. Jurnal Spektrum Pendidikan Luar Sekolah, 6(4).

Rudi Susilana dan Cepi Riyana. (2009). Media Pembelajaran: hakikat, pengembangan, pemanfaatan dan penilaian. Bandung: CV Wacana Prima.

Rusman. (2013). Metode-Metode Pembelajaran: Mengembangkan Profesionalisme Guru. Jakarta: PT RajaGrafindo Persada.

Sugiyono. (2017). Metode Peneltian Pendidikan: Pendekatan Kuantitatif, Kualitatif dan $R \& D$. Bandung: ALFABETA.

Sunarti, V. (2014). Peranan Pendidikan Luar Sekolah Dalam Rangka Mitigasi Bencana. II, 3141.

Susanto, A. (2013). Teori Belajar dan Pembelajaran di Sekolah Dasar. Jakarta: PT Kharisma Putra Utama.

Wiyani, A. . (2013). Manajemen Kelas. Yogjakarta: Ar-Ruzz Media. 